\title{
Tax Havens and Effective Tax Rates: An Analysis of Private versus Public European Firms
}

Thornton, J.S.; Jaafar, A.

\section{International Journal of Accounting}

DOI:

10.1016/j.intacc.2015.10.005

Published: 01/12/2015

Peer reviewed version

Cyswllt i'r cyhoeddiad / Link to publication

Dyfyniad o'r fersiwn a gyhoeddwyd / Citation for published version (APA):

Thornton, J. S., \& Jaafar, A. (2015). Tax Havens and Effective Tax Rates: An Analysis of Private versus Public European Firms. International Journal of Accounting, 50(4), 435-457.

https://doi.org/10.1016/j.intacc.2015.10.005

\footnotetext{
Hawliau Cyffredinol / General rights

Copyright and moral rights for the publications made accessible in the public portal are retained by the authors and/or other copyright owners and it is a condition of accessing publications that users recognise and abide by the legal requirements associated with these rights.

- Users may download and print one copy of any publication from the public portal for the purpose of private study or research

- You may not further distribute the material or use it for any profit-making activity or commercial gain

- You may freely distribute the URL identifying the publication in the public portal ?
}

Take down policy

If you believe that this document breaches copyright please contact us providing details, and we will remove access to the work immediately and investigate your claim. 
MS-12-08-348

Tax Havens and Effective Tax Rates:

An Analysis of Private versus Public European Firms

By

Aziz Jaafar* and John Thornton**

* Senior Lecturer in Accounting, The Business School, Bangor University, Hen Goleg, College Road, Bangor, Gwynedd LL57 2DG, United Kingdom. Tel: +44 (0) 1248 383226; fax: +44 (0) 1248 383228; e-mail: a.jaafar@bangor.ac.uk (Corresponding author).

** Professor of Economics, The Business School, Bangor University, Hen Goleg, College Road, Bangor, Gwynedd LL57 2DG, United Kingdom. Tel: +44 (0) 1248 388545; fax: +44 (0) 1248 383228; e-mail: j.thornton@ bangor.ac.uk.

This Draft:

$3^{\text {rd }}$ June 2015 
MS-12-08-348

\title{
Tax Havens and Effective Tax Rates:
}

\section{An Analysis of Private versus Public European Firms}

\begin{abstract}
We examine the impact of tax-haven operations on the effective corporate tax burdens of publicly listed and privately held firms domiciled in Europe. In particular, we consider how European firms' tax haven operations interact with factors such listing status and home-country tax reporting systems to determine the relative tax burdens of publicly listed and private firms. Our main empirical results show that tax haven operations are associated with lower effective tax rates for both private and public firms, and that the impact of tax havens in lowering effective tax rates is more pronounced for private firms than for public firms. Home country characteristics are also important determinants of effective tax rates for both private and public firms with tax havens. Given that firms use tax havens as tax avoidance mechanism in lowering tax burdens regardless of their listing status, regulatory and tax enforcement bodies should focus on private as well as public firms.
\end{abstract}

JEL Classification: H20, M41

Keywords: Effective tax rates, Publicly listed firms, Private firms, Tax havens 


\section{Tax Havens and Effective Tax Rates:}

\section{An Analysis of Private versus Public European Firms}

\section{Introduction}

The use of tax havens as a tax avoidance mechanism has come under increasing scrutiny from regulatory authorities and policymakers, especially in the context of the fiscal crisis that has afflicted many countries in recent years (Dyreng \& Lindsey, 2009; Maffini, 2010; Markle \& Shackelford, 2012a; Taylor \& Richardson, 2012). Tax havens are jurisdictions that impose no or very low corporate taxes and hence offer firms the ability to reduce their overall tax burdens in their home country. Accordingly, firms with affiliates in tax havens may experience lower overall tax burdens than firms without such affiliates because of the opportunities for intrafirm profit shifting from high-tax to low-tax jurisdictions (Desai, Foley, \& Hines, 2006). The use of tax havens among multinationals is ubiquitous. For example, in 2010 all but two of the 100 largest U.K. firms had affiliates in tax-haven jurisdictions (Grice, 2011), and 83 of the 100 largest publicly listed U.S. firms (in terms of revenue) reported having subsidiaries in jurisdictions listed as tax havens or financial privacy jurisdictions (Government Accountability Office [GAO], 2008). The European Commission estimates that around one trillion Euros (about $\$ 1.3$ trillion) is lost annually across the European Union (EU) member states mainly as a result of the exploitation of tax havens (Murphy, 2012).

Thus far, empirical studies examining the link between tax-haven operations and corporate tax burdens have focused exclusively on the experience of publicly listed firms and generally show that such firms with tax-haven affiliates are able to reduce their tax burdens in their home 
country (e.g., Dyreng \& Lindsey, 2009; Harris et al., 1993; Markle \& Shackelford, 2012a, 2012b). Empirical research on the tax behavior of private firms is an area that is generally relatively under-researched. The lack of evidence on the effective tax burden of these firms is unfortunate for at least two reasons: first, private firms are more numerous than publicly listed firms and typically make an important contribution to the economy ${ }^{1}$; and second, although public and private firms generally face the same tax regime, extant studies show that private firms are not constrained by financial reporting when reducing their tax burdens. That is, private firms are more likely to accept reductions in financial accounting income to lower their tax bills relative to public firms (e.g., Ball \& Shivakumar, 2005; Garrod, Kosi, \& Valentincic, 2008; Klassen, 1997; Kosi \& Valentincic, 2013; Peek, Cuijpers \& Buijink, 2010; Penno \& Simon, 1986; van Tendeloo \& Vanstraelen, 2008).

In this paper, we aim to offer a more comprehensive understanding of the impact of tax-haven operations on corporate tax burdens. First, we compare the impact of tax havens on the tax burden of private and public firms. Second, we look at the impact of a firm's home tax reporting system, i.e., the worldwide tax system (WWTS) and the territorial tax system (TTS), on firms' effective tax burdens. The WWTS has been adopted by only a few countries, including the US and the UK, and imposes the same tax rate on repatriated foreign profits as domestic profits; in contrast, under the TTS repatriated profits are not taxable which allows firms to locate their operations or to shift profits to foreign jurisdictions with low corporate tax rates. Several studies have shown the tax system to be an important determinant of the tax burden (e.g., Atwood, Drake, Myers, \& Myers, 2012; Hines, 2006; Hubbard 2006; Maffini, 2010; Markle, 2011; Markle \& Shackelford, 2012a), and that firms operating in countries that have adopted the

\footnotetext{
${ }^{1}$ In 2010, for instance, private firms accounted for $86 \%$ of US firms with 500 or more employees (Asker et al., 2014) and they generate $69 \%$ of private-sector employment, $59 \%$ of sales and $49 \%$ of aggregate pre-tax income.
} 
WWTS face higher tax burdens than do firms in countries that have adopted the TTS (Atwood et al., 2012; Maffini, 2010, Markle, 2011). Third, we examine how the home country tax reporting system interacts with the use of tax havens to determine the effective tax rates. Many previous studies have reported significant links between financial and tax reporting using public firms domiciled in the US (Atwood et al., 2012; Blaylock, Shevlin, \& Wilson, 2012; Wilson, 2009); however, we examine this issue for both public and private firms headquartered outside the US.

We employ financial statement information to estimate effective tax rates (ETRs) for the period 2001-08 for public and private firms domiciled in 14 European Union countries and in Norway and Switzerland and report four key findings. First, we find that tax haven operations are associated with lower effective tax rates for both private and public firms. Second, we show that the impact of tax havens in lowering effective tax rates is more pronounced in private firms than in public firms. Specifically, tax haven operations reduce the overall tax burdens on average by $5.33 \%$ in private firms vis-à-vis $1.56 \%$ in public firms. Third, we find that, regardless of the firm's home tax system, private firms with tax havens have lower effective tax rates vis-à-vis their public counterparts. Finally, our results show that private firms with tax havens domiciled in low degree of financial and tax conformity jurisdictions enjoy lower tax burdens. Our findings are robust to controlling for firm-specific characteristics that prior research has considered to be determinants of corporate tax burdens.

We are not aware of any previous study that attempts to compare the impact of tax havens on the tax burdens of privately held versus publicly listed firms. Consequently, we believe that our paper contributes to the tax and accounting literature in two important ways. First, we add to the limited empirical literature on the tax behavior of both privately and publicly held firms, 
especially with regard to their likely focus on tax avoidance. Second, the paper contributes to the extant literature on the impact of tax havens as well as firms' home country characteristics by providing cross-country empirical evidence from firms domiciled outside the US.

The rest of the paper is organized as follows. Section 2 provides a review of the relevant literature on tax havens and on firms' home-country characteristics, and develops testable hypotheses. Section 3 discusses our data and methodology and presents descriptive statistics. Section 4 presents our empirical results, and Section 5 concludes.

\section{Related Literature and Development of Hypotheses}

\section{Related Literature}

Tax havens are jurisdictions that impose no or very low corporate taxes and hence offer firms opportunities to reduce the overall tax burden in their country of domicile (Organization for Economic Cooperation and Development [OECD], 1998). Other characteristics of tax havens include lack of information sharing with foreign tax authorities and non-disclosure of regulatory and administrative requirements. ${ }^{2}$ In some cases, firms are not required to operate or to be physically present in tax havens (GAO, 2008). Table 1 lists the 38 tax-haven jurisdictions currently existing globally. ${ }^{3}$ Extant literature examining the impact of tax-haven operations typically focuses on public firms. For example, Harris et al. (1993) report that over the period 1984-88 the tax burden of U.S. public firms with tax-haven operations was significantly lower than those of otherwise-similar firms; and Dyreng and Lindsey (2009) find that U.S. public firms operating in tax haven territories between 1995-2007 had a 1.5

\footnotetext{
${ }^{2}$ Detailed discussions on issues and opportunities associated with tax havens can be found in Dharmapala (2008).

${ }^{3}$ We acknowledge that there is no universal list of tax havens as each organization has its own assessment criteria. The list of tax havens used here is based on the OECD classification, which is broadly similar to those used in prior literature, e.g., Dyreng and Lindsey (2009), and Dharmapala (2008).
} 
percentage points lower overall tax burden than firms without operations in tax-haven territories. Markle and Shackelford (2012b) is the only cross-country study to examine the impact of tax havens, and its findings show that the tax burden of public firms with tax-haven affiliates is significantly lower vis-à-vis public firms without tax-haven affiliates.

As mentioned above, many studies (e.g., Lee \& Swenson, 2012; Maffini, 2010) focus almost exclusively on public firms, but we also consider the tax behavior of private firms due to the latter's dominant role in many European countries. Berzins, Bøhren, and Rydland (2008), for instance, report that across Europe, over $90 \%$ of registered firms are privately held and that they generate four times higher revenues and control twice as many assets as publicly listed firms. Thus, analyzing the tax experience of private firms is of interest in its own right and offers a more comprehensive understanding of corporate tax burdens. However, as already noted, although there has been much research on the tax behavior of public firms, similar research relating to privately held firms is quite limited, especially for firms headquartered outside the US.

[Table 1 about here]

\section{Development of Hypotheses}

Both private and public European firms generally face similar financial reporting and tax regulations (Burgstahler, Hail, \& Leuz, 2006). In particular, prior to the adoption of the International Financial Reporting Standards (IFRS) in 2005 by public firms, financial statements for both private and public firms were drawn up using comparable reporting standards and were required to be audited. ${ }^{4}$ Private and public firms were also subjected to the same provisions in determining tax obligations. However, several factors could result in

\footnotetext{
${ }^{4}$ Exemptions from preparing financial statements are allowed for very small firms, and these firms are excluded from our analysis.
} 
different rates of usage of tax havens by public and private firms. On the one hand, greater usage by public firms might be encouraged by the fact that they face the capital market pressures with respect to profit performance that private firms do not, and that they are likely to have greater resources and available expertise to engage in tax planning. On the other hand, public firms are also more visible and the use of tax havens can attract more hostile attention from stakeholders generally, and though private firms do not face public scrutiny, they may have less incentive to use tax havens if their status allows them to engage in other less costly tax avoidance schemes. In addition, the different ownership structure and financial reporting objectives of private and publicly held firms has given rise to a significant variation in the demand from them for high quality and transparent financial information. In particular, private firms are more closely held and have greater managerial ownership (Chen, Hope, Li, \& Wang, 2011). In this setting, information asymmetry is typically alleviated using the "insider" model, given that the suppliers of funds are often actively involved in the decision-making process and in the monitoring of firm activities, and thus they have direct access to inside information (Ball \& Shivakumar, 2005; Van Tendeloo \& Vanstraelen, 2008). Furthermore, in comparison to public firms, private firms do not use financial statements as extensively in contracting and communicating with outside parties. Consequently, private firms have relatively less incentive to focus on reported earnings and are more likely to be driven by tax and other considerations (Ball \& Shivakumar, 2005; Beatty \& Harris, 1999). Based on the foregoing, we predict that tax haven operations are associated with lower effective tax rates for private firms as compared to public firms. Therefore, we formally hypothesize:

$\mathrm{H}_{1}$ : Tax haven operations are associated with lower ETRs in private firms, relative to public firms. 
Following Atwood et al. (2012), we also consider the impact of firms' home-country characteristics on the relative tax burden of private and public firms. The first characteristic we consider is the tax system used by the home country, given that it has been shown in the literature to be an important tax determinant (e.g., Atwood et al., 2012; Hines, 2006; Hubbard 2006; Maffini, 2010; Markle, 2011; Markle \& Shackelford, 2012a). In essence, a country can adopt either a worldwide or a territorial system in determining corporate taxes. ${ }^{5}$ Under a territorial tax system (TTS), repatriated foreign income is not taxable and, as a result, firms can reduce their tax burden by locating their operations or shifting their profits to jurisdictions with low or no corporate taxation. On the other hand, countries with a worldwide tax system (WWTS) impose the same tax rates on foreign income as domestic income, if and when it is repatriated to the home country (Blouin \& Krull, 2009). Consequently, firms domiciled in WWTS would, on average, face higher tax bills. In Europe, the UK changed from the WWTS to TTS in 2009, leaving Ireland and Greece as the only countries using the worldwide tax system. ${ }^{6}$ The US, South Korea, and Mexico remain the only major countries outside Europe using the worldwide tax system. This tax system has been criticized for its adverse impact on U.S. firms' competitiveness vis-à-vis multinationals headquartered in territorial tax system jurisdictions because of the additional tax burdens imposed on repatriated profits (Hines, 2006; Hubbard, 2006), and because it encourages firms to "park" profits generated from foreign operations outside their home country (Blouin et al., 2012). ${ }^{7}$ Maffini (2010) compares the tax burden under the worldwide and territorial tax systems of companies headquartered in 15 OECD countries and reports that the former face a higher corporate tax burden. Similarly, Markle (2011) finds that firms with home-country territorial tax systems shift more profits

\footnotetext{
${ }^{5}$ Detailed discussion on worldwide taxation versus territorial taxation can be found in Fleming, Peroni, and Shay (2008).

${ }^{6}$ Given that our dataset is only up to 2008 , the UK is classified as a worldwide tax system country for the purpose of our analysis. Greece is not included in our sample due to unavailability of data.

${ }^{7}$ For instance, the aggregate amount of undistributed income owned by U.S. multinationals in 2004 was estimated at US\$ 804 billion (Redmiles, 2008).
} 
among their foreign subsidiaries overall than do firms with home-country worldwide tax systems. Atwood et al. (2012) also find that tax avoidance is higher (lower) for firms in home countries with a territorial (worldwide) tax system in a study of firms in 22 countries between 1995 and 2007. Markle and Shackelford (2012a) is the only study we know of that finds a lower tax burden for firms headquartered in worldwide tax jurisdictions; using a dataset comprising publicly listed firms in 82 countries, they report that firms domiciled in WWTS, on average, enjoyed 1.4\% lower ETRs as compared to their counterparts in TTS. Based on the foregoing discussion, we hypothesize:

$\mathrm{H}_{2}$ : Home country tax system (i.e., WWTS vs. TTS) moderates the relation between tax haven use, and the ETRs of private versus public firms.

Another important home-country characteristic examined is the impact of conformity between financial reporting and tax reporting on effective tax rates. ${ }^{8}$ Examples of financial and tax reporting conformity include: (i) the use of financial accounting regulations for tax estimation or vice-versa; and (ii) the use of tax provisions for specified items in both the financial statements and the tax returns (Lamb, Nobes, \& Roberts, 1998; Shackelford \& Shevlin, 2001). ${ }^{9}$ For example, firms domiciled in jurisdictions with a high degree of financial-tax reporting conformity may have less opportunity to avoid taxes without decreasing reported income because financial accounting policy choices are directly linked to taxable income. In other words, financial-tax reporting conformity reduces firms' incentives to engage in upward

\footnotetext{
${ }^{8}$ Although the determination of taxable income is based on individual accounts, accounting policy choice used in consolidated accounts is often similar to that used in individual accounts, and likewise, mainly for reasons of simplicity and cost savings.

${ }^{9}$ For instance, until fiscal year 2009, the reverse authoritative principle (Maßgeblichkeitsprinzip, Sec. 5 (1) 1 EStG) was a dominant feature for financial and tax reporting in Germany where taxable income has to be determined in accordance with German accounting standards, and the recognition and measurement policies used in financial accounting must generally be consistently used in tax returns. This authoritative principle was abolished with the introduction of new regulation Accounting Law Modernization Act (BilMoG-Act) in 2010. Austrian firms are also subject to similar regulations.
} 
earnings manipulations as it also increases tax burdens (Coppens \& Peek, 2005; Desai \& Dharmapala, 2009; Lee \& Swenson, 2012). Furthermore, Atwood et al. (2012) argue that tax authorities act as an additional enforcement mechanism of financial reporting when higher conformity between reported earnings and taxable income is required.

As a result of increased monitoring and less flexibility in accounting policy choice, firms domiciled in high financial and tax conformity jurisdictions, on average, engage in fewer “creative accounting" activities (Desai, 2005). Firms in such countries may also trade off tax savings for income-increasing accounting choices, i.e., if firms decide to maximize reported earnings, the corresponding accounting methods used may increase taxable income and, thus, taxes (Lee \& Swenson, 2012). Although several studies have documented significant interactions between financial and tax reporting, such as financial and tax reporting aggressiveness (Frank, Lynch, \& Rego, 2009), tax avoidance (Blaylock et al., 2012), and tax sheltering (Wilson, 2009) in the U.S. context, little is known about these effects on corporate tax burdens in other jurisdictions. Although the degree of financial-tax reporting conformity varies considerably across European countries (Lee and Swenson, 2012), on the basis of prior relevant research studies (e.g., Alexander \& Archer, 1998; Coppens \& Peek, 2005; Lamb et al., 1998; Lee \& Swenson, 2012; McLeay, 1999), we classify Austria, Belgium, France, Germany, Italy, Norway, Portugal, Sweden, and Switzerland as countries with high financialtax conformity, and vice-versa for Denmark, Ireland, the Netherlands, Spain, and the UK. Empirical evidence shows that firms domiciled in jurisdictions with a lower (higher) degree of financial-tax conformity on average engage in more (less) tax avoidance activities. For example, using a cross-country dataset, Atwood et al. (2012) report firms engage in less tax avoidance when their home countries have higher book-tax conformity, while Lee and Swenson (2012) find that book-tax conformity rules increase tax burdens in publicly traded 
firms domiciled across the European Union. As mentioned earlier, private firms on average are less visible in term of public scrutiny, and they do not use financial statements as widely in communicating with outsiders. Hence, in comparison to public firms, private firms face fewer pressures to abide by the book-tax conformity rules in reducing ETRs. Based on the foregoing, we hypothesize:

$\mathrm{H}_{3}$ : Home country book-tax conformity (i.e., high vs. low book-tax conformity) moderates the relation between tax haven use, and the ETRs of private versus public firms.

We also consider several control variables that prior research has established to be determinants of effective corporate tax burdens. These controls include firm-level characteristics, such as the presence of foreign operations in non-tax-haven jurisdictions, firm size, leverage, performance, capital intensity, inventory intensity, and statutory tax rates at the county level. ${ }^{10}$ In particular, firms with foreign operations in non-tax havens are also more flexible in terms of structuring their activities to reduce their tax burden, including the shifting of profits to lowtax jurisdictions by, for example, manipulating international transfer pricing to foreign subsidiaries or vice versa, allocating high-interest loans to high-tax jurisdictions, or reassigning certain expenditures to countries with high-tax regimes to reduce reported earnings in them (Clausing, 2003; Gresik, 2001; Hines, 1999). In principle, this greater flexibility suggests that firms with foreign operations in non-tax havens also face lower ETRs than firms with domestic-only operations. Regarding firm size, larger firms might face higher ETRs because of their greater political visibility (Watts \& Zimmerman, 1986; Zimmerman, 1983) or because they find it more difficult to pursue tax planning (Scholes \& Wolfson, 1992), or they might face lower ETRs because they have greater resources available to manipulate the

\footnotetext{
${ }^{10}$ See Hanlon and Heitzman (2010) for a detail discussion of the determinants of effective tax rates.
} 
political process in their favor and engage in tax planning (Siegfried, 1974). A firm's financing decisions could affect its ETR if the tax laws allow for differential tax treatment contingent on its capital structure, for example, between equity and debt financing (Gupta \& Newberry, 1997). A firm's investment decisions might have an effect on the effective tax burden because of the tax treatment of depreciable assets (Stickney \& McGee, 1982), inventories (Zimmerman, 1983), and R\&D expenditures (Gupta \& Newberry, 1997). ${ }^{11}$ Similarly, debt financing can reduce the corporate tax burden since interest expenses are tax deductible, whereas dividends paid to shareholders are not tax deductible (Hanlon, 2003). Firm profitability is considered an important determinant of the effective tax burden because a change in operating results can lead to a change in the tax burden, with more profitable firms tending to have higher effective tax rates (Chen et al., 2010). Finally, several studies (Atwood et al., 2012; Devereux et al., 2008; Nicodème, 2001) point out that statutory tax rates for each country of domicile are also an important determinant of corporate tax rates.

\section{Measuring ETRs, data, and methodology}

\subsection{Measuring ETRs}

We employ the ETR as the measure of the corporate tax burden. It has been used widely in empirical tax research (e.g., Callihan, 1994; Hanlon \& Heitzman, 2010; Markle \& Shackelford, 2012a, 2012b; Nicodème, 2001; Shackelford \& Shevlin, 2001) because it provides a summary measure of cross-country differences in statutory tax rates (STRs) and tax incentives. Furthermore, ETRs provide an indication of whether firms with similar characteristics but located in different domiciles are subject to substantially different tax treatments. ETRs are typically computed by dividing some estimate of tax liability by income. ${ }^{12}$ Here, we use two

\footnotetext{
${ }^{11}$ We exclude R\&D intensity from our analysis, as it is not available for our dataset. Furthermore, the vast majority of private firms do not undertake R\&D activities.

${ }^{12}$ See Table 1 of Hanlon and Heitzman (2010, p.140) for alternative measures of ETRs used in the tax literature.
} 
measures to determine corporate tax burdens. Our first measure (ETR1) is calculated as firms' current tax expense divided by their pre-tax income, a measure that has been used in numerous empirical studies (e.g., Lee \& Swenson, 2012; Markle \& Shackelford, 2012a, 2012b; Richardson \& Lanis, 2007). This measure captures permanent book-tax differences and reflects the extent of aggressive tax planning (Chen et al., 2010). The second measure (ETR2) is calculated as firms' current tax expense divided by their operating cash flows. Cash flow from operations is used as an alternative measure as it mitigates systematic differences in accounting method choices across different jurisdictions (e.g., Gupta and Newberry, 1997; Zimmerman, 1983).

\subsection{The data}

Our data on private and public firms is from the Amadeus database compiled by Bureau Van Dijk. ${ }^{13}$ Our initial sample comprises all firm-year observations for both private and public firms domiciled in 14 European countries for which consolidated financial statements are available for the period 2001 to 2008. These countries are Belgium, Denmark, Finland, France, Germany, Ireland, Italy, the Netherlands, Norway, Portugal, Spain, Sweden, Switzerland, and the UK. The choice of countries included in our sample is based on the availability of data. We use consolidated accounts in order to alleviate the difference between reported and taxable profits, as well as timing differences arising from either semi-permanent or permanent discrepancies (Buijink et al., 2002). To arrive at our final sample, we winsorize firms whose ETR is greater than one or less than zero, and firms with missing values for variables employed in our statistical models. We also winsorize all continuous variables at the top and bottom $1 \%$ in order to mitigate the influence of outliers. Our final sample for ETR1 (ETR2) consists of 135,578

\footnotetext{
${ }^{13}$ More specifically, we use the April 2010 version of Amadeus to source all variables except for tax-haven and foreign non-tax-haven affiliates. With respect to tax-haven and foreign non-tax-haven affiliates, the dataset provided by Amadeus is time-invariant; hence, we collate these two variables for each sampled year using the historical Amadeus database available on CD ROMs.
} 
$(124,666)$ firm-year observations for private firms and 13,303 $(12,330)$ firm-year observations for public firms.

\subsection{Research methodology}

We employ a fixed effects regression model separately for private and public firms and control for sector of operations, country of domicile, and year dummies. Furthermore, we use robust regression techniques to mitigate the influence of outliers in all specifications. Our first regression model is as follows:

$$
\operatorname{ETR}_{i t}=\beta_{0}+\beta_{1} \text { TAXHAVEN } N_{i t}+\text { Controls }+\varepsilon_{i c t}
$$

where ETR is either ETR1 or ETR2, and TAXHAVEN is a dummy variable taking the value of 1 if a firm has a foreign subsidiary in a tax-haven jurisdiction, and 0 otherwise. The control variables are: a dummy variable taking the value of 1 if a firm has a foreign subsidiary in a non-tax-haven jurisdiction, and 0 otherwise, NONHAVENMNC ${ }^{14}$; a measure of firm size, which is the natural log of total assets, SIZE; a measure of leverage, which is the ratio of total long-term debt to total assets, $L E V$; a measure of firm performance, which is the ratio of pretax operating profit to total assets, PERF; the ratio of property, plant, and equipment to total assets, CAPINT; the ratio of inventories to total assets, INVINT; and the statutory tax rate in each country and in each year, STR. We predict that the coefficient $\beta_{1}$ for TAXHAVEN is negative for both private and public firms, indicating that operations in tax-haven jurisdictions reduce the effective tax rates. To the extent that private firms are more aggressive in lowering tax burdens, we also expect the $\beta_{1}$ for private firms to be larger (more negative) than that of public firms.

\footnotetext{
${ }^{14}$ Here, we are testing across three groups: (i) MNCs with foreign subsidiaries in tax havens (TAXHAVEN); (ii) MNCs with foreign subsidiaries in non-tax havens (NONHAVENMNC); and (iii) domestic firms that by definition do not have foreign subsidiaries. Hence, the NONHAVENMNC control variable is not merely the inverse (i.e., the zeroes) of the TAXHAVEN variable.
} 
In order to confirm our results in Model (1), we also estimate a pool regression using the following specification:

ETR $_{i t}=\beta_{0}+\beta_{1}$ PRIVATE $_{i t}+\beta_{2}$ TAXHAVEN $N_{i t}+\beta_{3}$ PRIVATE $*$ TAXHAVEN $i t+$ Controls $+\varepsilon_{i c t}$

where ETR, TAXHAVEN, and the control variables are defined as in the regression model (1), and PRIVATE is a dummy variable taking the value of 1 if a firm is privately-held, and 0 if a firm is publicly-held. Consistent with model (1) above, we expect coefficients $\beta_{1}$ and $\beta_{2}$ to be negative. We extend our analysis by assessing the influence of firms' home country characteristics on private and public firms with tax havens. In so doing, we simultaneously run model (2) using seemingly unrelated estimation (SUEST) for (i) WWTS and TTS, and (ii) high and low TAXCONF. For ease of reference, the definitions of the variables are summarized in Table 2.

[Table 2 about here]

\section{Empirical results}

\subsection{Descriptive Statistics}

Table 3 provides a summary of mean statutory tax rates (STR), ETR1, and ETR2 during the sample period. The three main points to note are: (i) the marked cross-country differences in STRs and ETRs; (ii) the ETRs between public and private firms, and the ETRs between firms with and without tax-haven operations, appear to be different, and across all countries; in particular, the ETRs of firms with tax havens are lower than firms without tax havens; and (iii) the ETRs are generally lower than the STRs with the exception of Italy and Ireland where 
average ETRs are higher than average STRs. This appears to be due mainly to additional sectorspecific or regional taxes faced by the firms domiciled in these jurisdictions. ${ }^{15}$

[Table 3 about here]

Table 4 provides summary statistics for the control variables, for private and public firms, and for such firms with tax haven operations. Private make much less use of tax havens than do private firms, they are smaller in size, use a higher proportion of debt financing, are marginally more profitable, and have a higher asset mix than public firms. Moreover, the firms with tax havens have different characteristics than firms without them; this is consistent with the prior literature (e.g. Dyreng \& Lindsey, 2009). For example, firms operating in tax havens are larger in terms of total assets and more profitable than firms without tax-haven operations.

Table 5 presents correlation coefficients among the explanatory variables for private firms and public firms. The results show high correlations between HIGHTAXJUR and STR (0.659 and 0.720 for private and public firms, respectively), between TAXCONF and WWTS (-0.666 and 0.798 for private and public firms, respectively), and to a lesser degree between TAXCONF and HIGHTAXJUR (-0.401 and -0.208 for private and public firms, respectively). However, these highly correlated variables are not included in the same regression model. The other correlation coefficients are relatively low, indicating that multicollinearity is unlikely to be an issue in our regression estimates.

[Tables $4 \& 5$ about here]

\footnotetext{
${ }^{15}$ For example, the regional administrative tax rate (Imposta sul Reddito delle Attivita Produttive, IRAP) for Italian firms was $4.25 \%$ in 2001, in addition to a $36 \%$ tax rate imposed by the central government, making for an overall STR of $40.25 \%$ (Manzo, 2011). In the case of Ireland, the tax rate imposed on real estate is considerably higher than the general tax rate on corporate profits (Elschner \& Vanborren, 2009).
} 


\subsection{Regression results}

Regression results for the baseline model are reported in Table 6. The results indicate a strong, negative, and statistically significant impact of tax haven operations on effective corporate tax rates for private and public firms and for both measures of the effective tax burden. Moreover, the impact of tax-haven operations on lowering the tax burden appears to be more pronounced in the case of private firms. The coefficients on the tax haven variable are $-0.0533(p$ value $<0.01)$ for private firms and $-0.0156(p$-value $<0.01)$ for public firms in the case of ETR1, and -0.0385 ( $p$-value $<0.01$ ) for private firms and -0.0225 ( $p$-value $<0.01)$ for public firms in the case of ETR2. This is consistent with tax havens allowing firms to engage in tax avoidance activities by shifting taxable income to those jurisdictions, regardless of listing status. Indeed, the impact of tax havens in lowering corporate tax burdens is persistent across all of our subsequent regression models. In terms of the economic significance, our results show that tax haven operations reduce the overall tax burden on average by $5.33 \%(3.85 \%)$ in private firms vis-à-vis $1.56 \%(2.25 \%)$ in public firms using the ETR1 (ETR2) measure. ${ }^{16}$ The Chow test show that the difference in the coefficients between private and public firms is negative and highly significant, i.e., $-0.0370(-0.0160)$ for ETR (ETR2). Thus, this result confirms our conjecture as well as those in the prior literature (e.g., Ball \& Shivakumar, 2005) that tax determination is considered to be more important in a private than a public firm setting.

With respect to the control variables, the results indicate that the presence of foreign operations in non-tax havens (NONHAVENMNC) is an important determinant of the ETR. The estimated coefficients on NONHAVENMNC are negative and highly significant in the case of private firms for both ETR measures, and for public firms in the case of the ETR2 measure of the tax burden. Hence, it appears that both private and public firms engage in tax avoidance

\footnotetext{
${ }^{16}$ Although the sample and estimation model are different, our result for European public firms is very similar to that of US public firms reported by Dyreng and Lindsey (2009).
} 
mechanisms; this is similar to findings of prior U.S. studies using public listed firms (Cazier et al., 2009; Rego, 2003; Wilson, 2009). Of the firm-specific variables, the estimated coefficients on firm size (SIZE) are consistently positive and statistically significant in all cases for both measures of the tax burden. The results imply that larger firms pay higher taxes in the EU than do smaller firms; this is consistent with Zimmerman's (1983) "political costs" hypothesis. The coefficients on firm leverage ( $L E V)$, capital intensity (CAPINT), and inventory intensity (INVINT) are negative and are always highly significant. This is consistent with the notion that firms use these variables as tax shields (e.g., Gupta \& Newberry, 1997; Lee \& Swenson, 2012; Markle \& Shackelford, 2012b; Stickney \& McGee, 1982). The coefficients on firm profitability $(P E R F)$ are positive and highly significant, indicating that more profitable privately owned firms face a higher effective tax rate (Gupta \& Newberry, 1997). Finally, the coefficients on statutory tax rates $(S T R)$ are consistently positive and highly significant in all models, suggesting that higher home-country tax rates are associated with higher corporate tax rates; this is similar to prior research (e.g., Lee \& Swenson, 2012).

[Table 6 about here]

The pool regression results for both private and public firms are reported in Model 1 of Table 7, which excludes the coefficients on the control variables because of space considerations. ${ }^{17}$ The results confirm the baseline findings reported in Table 6. That is, for both ETR measures, the estimated coefficients of TAXHAVEN are negative and statistically significant for all models, which is consistent with prior literature that firms use tax haven operations to lower ETRs. The PRIVATE*TAXHAVEN interaction term is negative and highly significant, implying that the impact of tax-haven operations on lowering tax burdens is more pronounced

\footnotetext{
${ }^{17}$ We include the same control variables as in Table 6.
} 
in the case of private firms. As the higher percentage of private firms relative to public firms in our sample may influence the empirical results, we follow prior literature (e.g. Dittmar et al., 2003) and use a weighted least squares (WLS) regression to ensure that both private and public firms receive equal weight in the regression estimations. The WLS result is reported in Model 2 of Table 7 and shows that the coefficient of PRIVATE*TAXHAVEN interaction is qualitatively similar to the main result. Hence, our empirical result is not influenced by the unequal sample size of private and public firms.

[Table 7 about here]

Next, we consider two important firm home-country characteristics as moderating variables of effective corporate tax rates, i.e., (i) home country tax systems and (ii) financial and tax conformity. We simultaneously run model (2) using seemingly unrelated estimation (SUEST) for firms domiciled in world-wide tax system (WWTS) and territorial tax system (TTS) jurisdictions. Panel A of Table 8 shows that, except for ETR1 of WWTS, the coefficients on TAXHAVEN are negative in all estimates. That is, regardless of home-country tax systems, our results show that the use of tax havens lowers ETRs for both public and private firms. The estimated coefficients on PRIVATE*TAXHAVEN are negative and statistically significant in all models, which suggests that ETRs for private firms with tax haven operations are lower relative to public firms. Taken together, our results appear to suggest that private firms with tax havens are more tax aggressive vis-à-vis public firms, regardless of the home country tax system. Panel B of Table 8 reports results for the book-tax conformity (TAXCONF) where we also simultaneously estimate high and low TAXCONF using SUEST. The estimated coefficients on TAXHAVEN are negative and highly significant for firms domiciled in low TAXCONF countries. The coefficients on the PRIVATE*TAXHAVEN interaction terms are negative and 
highly significant for ETR1, suggesting that the use of tax havens by private firms bring economic benefits in lowering effective tax rates, which is consistent with our hypothesis.

[Table 8 about here]

\subsection{Additional analyses}

In this section, we extend our analysis and offer robustness to our main conclusions. To economize on space the results are not tabulated. ${ }^{18}$ First, we partition the sample into high-tax and low-tax jurisdiction countries, which we define as jurisdictions in which firms' ETRs are above and below the median in each year, respectively. We then examine whether tax haven operations by firms headquartered in high-tax jurisdiction countries is an important determinant of tax burdens. ${ }^{19}$ As in the main analysis, the estimated coefficients on PRIVATE are negative and highly significant regardless of whether private firms operate in high or low tax jurisdictions. The coefficients of the interaction effects on PRIVATE and TAXHAVEN are also similar to those in the main analysis, i.e., negative and significant. Second, to match between public and private firms of similar sizes, we re-estimate the main regression (2) but only for larger firms in the sample (thereby excluding a large number of smaller private firms from the sample). The empirical results are qualitatively similar to those reported in Table 7, i.e., they indicate that private firms are more aggressive in avoiding tax through tax-haven operations than are public firms. Finally, as our research period coincides with the mandatory adoption of the IFRS in 2005 for public European firms, we also tested for the effects of these standards on firms' ETRs by incorporating into the estimate a 0,1 dummy variable representing their

\footnotetext{
${ }^{18}$ The results are available from the corresponding author on request.

${ }^{19}$ We include the same control variables as in the main analysis except for STR because of its high correlation with HIGHTAXJUR.
} 
adoption. The results suggest that adoption of IFRS had little impact on the corporate tax burden of publicly listed firms, which is consistent with results reported by Eberhartinger and Klostermann (2007).

\section{Conclusions}

In this study, we have assessed the impact of tax havens on the relative effective tax burden of private and publicly listed firms domiciled in Europe. We believe that this is the first study to offer a comprehensive analysis of tax avoidance by means of tax-haven affiliates of firms, regardless of their listing status. Our principal result is that tax havens is used as a tax avoidance mechanism by both privately held and publicly listed firms, and that the impact of tax havens in lowering effective tax rates is more pronounced in privately held firms than in publicly listed firms. Furthermore, our findings indicate that firms' home-country characteristics (i.e., a worldwide tax reporting system, financial and tax conformity, as well as high corporate tax rates) are important in determining effective tax rates.

Our findings have several potential implications for E.U. corporate tax policymakers. In particular, they should assist tax watchdogs in their efforts to understand the tax behavior of both privately held and publicly listed firms. To the extent that firms evidently benefit from using tax havens as a tax avoidance mechanism regardless of their listing status, tax compliance and enforcement authorities should focus not only on public firms but also on private firms. Indeed, despite the relatively low proportion of private firms using tax havens, our empirical results show that such firms are more aggressive in avoiding tax through tax-haven operations than are public firms. Furthermore, substantial progress still needs to be made in the E.U. member states that currently have varying standards as to the treatment of tax havens and therefore different provisions for dealing with them. 
Finally, our study is subject to two limitations. First, our ETR measures are drawn from financial statements prepared for investors and not for tax authorities, as data on tax returns are private and unavailable. Hence, our results should be interpreted with some caution. Second, our empirical analysis is based on the premise that tax haven operations affects corporate tax burdens, but we acknowledge that it is difficult to establish causality in this line of research. Nonetheless, we believe that this is the best endeavor to date to analyze comprehensively the tax behavior of both private and public firms in Europe. It would be useful for future research to examine the propensity for a firm to use a tax haven, and whether this is different between public and private firms. 


\section{References}

Alexander, D., \& Archer, S. (1998). European accounting guide. London: Harcourt Brace Professional Publishing.

Asker, J., Farre-Mensa, J., \& Ljungqvist, A. (2014). Does the stock market harm investment incentives? Working paper, New York University.

Atwood, T., Drake, M., Myers, J., \& Myers, L. (2012). Home country tax system characteristics and corporate tax avoidance: International evidence. The Accounting Review, 87(6), 1831-1860.

Ball, R., \& Shivakumar, L. (2005). Earnings quality in UK private firms: Comparative loss recognition timeliness. Journal of Accounting and Economics, 39(1), 83-28.

Beatty, A., \& Harris, D. (1999). The effects of taxes, agency costs and information asymmetry on earnings management: A comparison of public and private firms. Review of Accounting Studies, 4, 299-326.

Berzins, J., Bøhren, Ø., \& Rydland, P. (2008). Corporate finance and governance in firms with limited liability: Basic characteristics. Working paper. Norwegian School of Management. Retrieved from http://www.bi.edu/OsloFiles/ccgr/RR/ BBR_complete_v34\%2020081034.pdf

Blaylock, B., Shevlin, T., \& Wilson, R. (2012). Tax avoidance, large positive book-taxdifferences, and earnings persistence. The Accounting Review, 87, 91-120.

Blouin, J., \& Krull, L. (2009). Bringing it home: A study of the incentives surrounding the repatriation of foreign earnings under the American Jobs Creation Act of 2004. Journal of Accounting Research, 47(4), 1027-1059.

Blouin, J., Krull, K., \& Robinson, L. (2012). Is U.S. multinational dividend repatriation policy influenced by reporting incentives? The Accounting Review, 87(5), 1463-1491.

Buijink, W., Janssen, B., \& Schols, Y. (2002). Evidence of the effect of domicile on corporate 
effective tax rates in the European Union. Journal of International Accounting, Auditing and Taxation, 11(1), 115-130.

Burgstahler, D., Hail, L., \& Leuz, C. (2006). The importance of reporting incentives: Earnings management in European private and public firms. The Accounting Review, 81(5), 9831016.

Callihan, D. S. (1994). Corporate effective tax rates: A synthesis of the literature. Journal of Accounting Literature, 12(1), 1-43.

Cazier, R., Rego, S., Tian, X., \& Wilson, R., (2009). Early evidence on the determinants of unrecognized tax benefits. Working paper, University of Iowa.

Chen, F., Hope, O., Li, Q., \& Wang, X. (2011). Financial reporting quality and investment efficiency of private firms in emerging markets. The Accounting Review, 86(4), 12551288.

Chen, S., Chen, X., Cheng, Q., \& Shevlin, T. (2010). Are family firms more tax aggressive than non-family firms? Journal of Financial Economics, 95, 41-61.

Clausing, K. A. (2003). Tax-motivated transfer pricing and US intrafirm trade prices. Journal of Public Economics, 87(9-10), 2207-2223.

Coppens, L., \& Peek, E. (2005). An analysis of earnings management by European private firms. Journal of International Accounting, Auditing and Taxation, 14(1), 1-17.

Desai, M. (2005). The degradation of reported corporate profits. The Journal of Economic Perspectives, 19, 171-193.

Desai, M., \& Dharmapala, D. (2009). Earnings management, corporate tax shelters, and booktax alignment. National Tax Journal, 62, 169-186.

Desai, M., Foley, C., \& Hines Jr., J. (2006). The demand for tax haven operations. Journal of Public Economics, 90(3), 513-531.

Devereux, M., Lockwood, B., \& Redoano, M. (2008). Do countries compete over tax rates? 
Journal of Public Economies, 92, 1210-1235.

Dharmapala, D., (2008). What problems and opportunities are created by tax havens? Oxford Review of Economic Policy, 24(4), 661-679.

Dittmar, A., Mahrt-Smith. J., \& Servaes, H. (2003). International Corporate Governance and Corporate Cash Holdings. Journal of Financial and Quantitative Analysis, 38, 111133.

Dyreng, S.D., \& Lindsey, B.P. (2009). Using financial accounting data to examine the effect of foreign operations located in tax havens and other countries on U.S. tax rates. Journal of Accounting Research, 46(5), 1283-1316.

Eberhartinger, E., \& Klostermann, M. (2007). What if IAS/IFRS were a tax base? New empirical evidence from an Austrian perspective. Working Paper 1090, Vienna University. Retrieved from http://epub.wu.ac.at/1096/

Elschner, C., \& Vanborren, W. (2009). Corporate tax rates in an enlarged European Union. Taxation Working Paper No. 33071, European Commission. Retrieved from http://ec.europa.eu/taxation_customs/resources/documents/taxation/gen_info/economic _analysis/tax_papers/taxation_paper_14_en.pdf

Fleming, J., Peroni, R., \& Shay, S. (2008). Some perspectives from the United States on the worldwide taxation vs. territorial taxation debate. Journal of the Australian Tax Teachers Association, 3(2), 35-86.

Frank, M., Lynch, L., \& Rego, S. (2009). Tax reporting aggressiveness and its relation to aggressive financial reporting. The Accounting Review, 84, 467-496.

Garrod, N., Kosi, U., \& Valentincic, A. (2008), Asset write-offs in the absence of agency problems. Journal of Business Finance \& Accounting, 35, 307-330.

Government Accountability Office (GAO) (2008). Cayman Islands: Business and tax advantages attract U.S. persons and enforcement challenges exist. Report to the 
Committee on Finance, U.S. Senate, GAO-08-778. Retrieved from http://www.gao.gov/new.items/d08778.pdf

Gresik, T. (2001). The taxing task of taxing transnationals. Journal of Economic Literature, $39(3), 800-838$.

Grice, A. (2011, October 11). British firms attacked for routine use of tax havens. The Independent, Retrieved from http://www.independent.co.uk/news/business/news/britishfirms-attacked-for-routine-use-of--tax-havens-2368753.html

Gupta, S., \& Newberry, K. (1997). Determinants of the variability in corporate effective tax rates: Evidence from longitudinal data. Journal of Accounting and Public Policy, 16(1), $1-34$.

Hanlon, M. (2003). What can we infer about a firm's taxable income from its financial statements? National Tax Journal, 56(4), 831-863.

Hanlon, M., \& Heitzman, S. (2010). A review of tax research. Journal of Accounting and Economics, 50, 127-178.

Harris, D., Morck, R., Slemrod, J., \& Yeung, B. (1993). Income shifting in U.S. multinational corporations. In A. Giovannini, R. G. Hubbard, and J. Slemrod (Eds.), Studies in international taxation (pp. 277-308). Chicago, IL: University of Chicago Press.

Hines, J. R. (1999). Lessons from behavioral responses to international taxation. National Tax Journal, 52(2), 304-322.

Hines, J. (2006). Testimony before the House Ways and Means Committee. Retrieved from http://waysandmeans.house.gov/UploadedFiles/Hines.pdf

Hubbard, R. G. (2006, June 22). Testimony before the House Ways and Means Committee. Retrieved from http://waysandmeans.house.gov/media/transcript/10197. html\#Hubbard

Klassen, K. J. (1997). The impact of insider ownership concentration on the trade-off between financial and tax reporting. The Accounting Review, 72(3), 455-474. 
Kosi, U., \& Valentincic, A. (2013). Write-offs and profitability in private firms: Disentangling the impact of tax-minimization incentives. European Accounting Review, 22(1) 117-150.

Lamb, M., Nobes, C., \& Roberts, A. (1998). International variations in the connections between tax and financial reporting. Accounting and Business Research, 28(3) 173-188.

Lee, N., \& Swenson, C. (2012). Are multinational corporate tax rules as important as tax rates? International Journal of Accounting, 47, 155-167

Liu, X., \& Cao, S. (2007). Determinants of corporate effective tax rates. China Economy, 40(6), $49-67$.

Maffini, G. (2010). Territoriality, worldwide principle and competitiveness of multinationals: A firm-level analysis of tax burdens. Working paper 12/10. Oxford University Centre for Business Taxation.

Manzo, M. (2011). Corporate taxation and SMEs: The Italian experience. Taxation Working Paper No. 6, OECD. Retrieved from http://www.oecdilibrary.org/docserver/download/5kg3h0th7t7c.pdf?expires=1379410654\&id=id\&accna me $=$ guest $\&$ checksum=DCE777393FBE0A9BE03513CDFABA764B

Markle, K. (2011). A comparison of the tax-motivated income shifting of multinationals in territorial and worldwide countries. Working paper, University of Waterloo, Ontario, Canada.

Markle, K., \& Shackelford, D. A. (2012a). Cross-country comparisons of corporate income taxes. National Tax Journal, 65, 493-528.

Markle, K., \& Shackelford, D. A. (2012b). Cross-country comparisons of the effects of leverage, intangible assets and tax havens on corporate income taxes. Tax Law Review, $65,415-432$.

McLeay, S., (1999). Accounting regulation in Europe. London: MacMillan Press. 
Mills, L., Erikson, M. M., \& Maydew, E. L. (1998). Investments in tax planning. Journal of the American Taxation Association, 33(1), 1-20.

Murphy, R. (2012). Closing the European tax gap: Report to the European Parliament. Retrieved from http://europeansforfinancialreform.org/en/system/files/ 3842_en_richard_murphy_eu_tax_gap_en_120229.pdf

Nicodème, G. (2001). Computing effective corporate tax rates: Comparison and results. MPRA Paper 3808. University Library of Munich, Germany. Retrieved from http://mpra.ub.unimuenchen.de/3808/

Organization for Economic Cooperation and Development (OECD) (1998). Harmful tax competition: An emerging global issue. Retrieved from http://www.oecd.org/tax/transparency/44430243.pdf

Organization for Economic Cooperation and Development (OECD) (2011). Corporate and capital income taxes, OECD Tax Database. Retrieved from http://www.oecd.org/document/60/0,3746,en_2649_34533_1942460_1_1_1_1,00.html \#C_CorporateCaptial

Peek, E., Cuijpers, R., \& Buijink, W. (2010). Creditors' and shareholders' reporting demands in public versus private firms: Evidence from Europe. Contemporary Accounting Research, 27, 49-91.

Redmiles, M. (2008). The one-time received dividend deduction. Statistics of Income Bulletin, $27,102-114$,

Rego, S. O. (2003). Tax-avoidance activities of U.S. multinational corporations. Contemporary Accounting Research, 20(4), 805-833.

Richardson, G., \& Lanis, R. (2007). Determinants of the variability in corporate effective tax rates and tax reform: Evidence from Australia. Journal of Accounting and Public Policy, 26(6), 689-704. 
Scholes, M. S., \& Wolfson, M. A. (1992). Taxes and business strategy: A planning approach. Englewood Cliffs, NJ: Prentice-Hall.

Shackelford, D. A., \& Shevlin, T. (2001). Empirical tax research in accounting. Journal of Accounting and Economics, 31, 321-387.

Shevlin, T., \& Porter, A. (1992). The corporate tax comeback in 1987: Some further evidence. Journal of the American Taxation Association, 14(1), 58-79.

Siegfried, J. J. (1974). Effective average U.S. corporation income tax rates. National Tax Journal, 27(2), 245-259.

Stickney, C., \& McGee, V. (1982). Effective corporate tax rates: The effect of size, capital intensity, leverage and other factors. Journal of Accounting and Public Policy, 1(2), 125152.

Taylor, G., \& Richardson, G. (2012). International corporate tax avoidance practices: Evidence from Australian firms. International Journal of Accounting, 47, 469-496.

Vandenbussche, H., Crabbé, K., \& Janssen, B. (2005). Is there regional tax competition? Firm level evidence for Belgium. De Economist, 153(3), 257-276.

Van Tendeloo, B., \& A. Vanstraelen. (2008). Earnings management and audit quality in Europe: Evidence from the private client segment market. European Accounting Review, 17(3), 447-469.

Watts, R., \& Zimmerman, J. (1986). Towards a positive theory of accounting. Englewood Cliffs, NJ: Prentice-Hall.

Wilson, R. (2009). An examination of corporate tax shelter participants. The Accounting Review, 84(3), 969-999.

Zimmerman, J. (1983). Taxes and firm size. Journal of Accounting and Economics, 5(1), 119149. 
Table 1

Tax haven countries and territories

\begin{tabular}{ll}
\hline Andorra & Maldives \\
Anguilla & Malta \\
Antigua and Barbados & Marshall Islands \\
Aruba & Mauritius \\
Bahamas & Monaco \\
Bahrain & Montserrat \\
Barbados & Nauru \\
Belize & Netherlands Antilles \\
Bermuda & Niue \\
British Virgin Islands & Panama \\
Cayman Islands & St Kitts and Nevis \\
Channel Islands & St. Vincent and the Grenadines \\
Cook Islands & Samoa \\
Cyprus & San Marino \\
Dominica & Seychelles \\
Grenada & Tonga \\
Isle of Man & Turks and Caicos \\
Liberia & Vanuatu \\
Liechtenstein & Virgin Island (US) \\
\hline Souce: OECD (2011)
\end{tabular}

Source: OECD (2011) 
Table 2

Variable definitions

\begin{tabular}{|c|c|c|}
\hline Variable & Description & Definition \\
\hline ETRI & Effective tax rate, first measure & Current tax expense divided by pre-tax income \\
\hline ETR2 & Effective tax rate, second measure & $\begin{array}{l}\text { Current tax expense divided by cash flow from } \\
\text { operations }\end{array}$ \\
\hline TAXHAVEN & Tax haven & $\begin{array}{l}\text { Set to } 1 \text { if a firm has a foreign subsidiary in a tax-haven } \\
\text { jurisdiction and } 0 \text { otherwise }\end{array}$ \\
\hline PRIVATE & Privately-held firm & Set to 1 if a firm is privately-held and 0 otherwise \\
\hline NONHAVENMNC & Foreign operations & $\begin{array}{l}\text { Set to } 1 \text { if a firm has a foreign subsidiary in a non-tax- } \\
\text { haven jurisdiction and } 0 \text { otherwise }\end{array}$ \\
\hline$W W T S$ & Worldwide tax system & $\begin{array}{l}\text { Set to } 1 \text { if a firm is headquartered in a jurisdiction with a } \\
\text { worldwide tax system and } 0 \text { otherwise }\end{array}$ \\
\hline$T T S$ & Territorial tax system & $\begin{array}{l}\text { Set to } 1 \text { if a firm is headquartered in a jurisdiction with a } \\
\text { territorial tax system and } 0 \text { otherwise }\end{array}$ \\
\hline TAXCONF & $\begin{array}{l}\text { Financial-tax conformity } \\
\text { jurisdiction }\end{array}$ & $\begin{array}{l}\text { Set to } 1 \text { if a firm is headquartered in a jurisdiction whose } \\
\text { financial reporting is closely linked with tax reporting } \\
\text { and } 0 \text { otherwise }\end{array}$ \\
\hline SIZE & Firm size & Natural log of total assets \\
\hline LEV & Leverage & Ratio of total long-term debt to total assets \\
\hline CAPINT & Capital intensity & Ratio of property, plant, and equipment to total assets \\
\hline INVINT & Inventory intensity & Ratio of inventory to total assets \\
\hline PERF & Profitability & Ratio of pre-tax operating profit to total assets \\
\hline STR & Statutory tax rate & Statutory tax rate in each jurisdiction and in each year \\
\hline
\end{tabular}


Table 3

Mean STR, ETR1, and ETR2

\begin{tabular}{|c|c|c|c|c|c|c|c|c|c|}
\hline & \multicolumn{5}{|c|}{ ETR1 } & \multicolumn{4}{|c|}{ ETR2 } \\
\hline & STR & Private & Public & $\begin{array}{c}\text { Private } \\
\text { Tax Haven }\end{array}$ & $\begin{array}{c}\text { Public } \\
\text { Tax Haven }\end{array}$ & Private & Public & $\begin{array}{c}\text { Private } \\
\text { Tax Haven }\end{array}$ & $\begin{array}{c}\text { Public } \\
\text { Tax Haven }\end{array}$ \\
\hline \multirow[t]{2}{*}{ Belgium } & 35.54 & 27.70 & 25.84 & 21.45 & 22.73 & 23.76 & 22.77 & 23.13 & 22.96 \\
\hline & & (3091) & (421) & (108) & (43) & $(3171)$ & (348) & $(92)$ & (34) \\
\hline \multirow[t]{2}{*}{ Denmark } & 28.25 & 25.15 & 26.96 & 20.05 & 18.38 & 22.93 & 21.66 & 18.65 & 22.41 \\
\hline & & (7884) & (300) & (36) & $(22)$ & (7654) & (277) & (36) & (21) \\
\hline \multirow[t]{2}{*}{ Finland } & 27.50 & 24.15 & 26.41 & 0.82 & 25.16 & 21.41 & 22.59 & 0.62 & 24.83 \\
\hline & & (8920) & (561) & (5) & (31) & (9146) & (492) & (5) & (26) \\
\hline \multirow[t]{2}{*}{ France } & 35.12 & 25.06 & 25.61 & 28.55 & 26.33 & 25.63 & 26.40 & 28.41 & 26.41 \\
\hline & & (1462) & (1954) & (10) & (174) & (1349) & (1921) & (9) & (170) \\
\hline \multirow[t]{2}{*}{ Germany } & 37.97 & 26.38 & 28.01 & 28.10 & 27.24 & 22.31 & 26.67 & 19.93 & 27.83 \\
\hline & & (12979) & (2314) & (6) & $(62)$ & (13156) & (2130) & (5) & $(58)$ \\
\hline \multirow[t]{2}{*}{ Ireland } & 13.88 & 19.94 & 15.68 & 7.18 & 7.95 & 31.63 & 18.09 & 5.21 & 9.64 \\
\hline & & (4936) & (144) & (1) & (10) & (2249) & (98) & (1) & (7) \\
\hline \multirow[t]{2}{*}{ Italy } & 33.19 & 39.46 & 33.88 & 33.45 & 27.92 & 36.47 & 32.14 & 31.77 & 25.32 \\
\hline & & (12463) & (667) & $(83)$ & (32) & (12941) & (661) & $(82)$ & (33) \\
\hline \multirow[t]{2}{*}{ Netherlands } & 31.33 & 25.54 & 23.18 & 23.71 & 20.42 & 23.20 & 22.03 & 19.22 & 16.33 \\
\hline & & (8895) & (448) & (269) & $(82)$ & (3341) & (179) & (103) & (30) \\
\hline \multirow[t]{2}{*}{ Norway } & 28.00 & 21.02 & 23.58 & 9.98 & 17.58 & 21.28 & 21.12 & 6.91 & 15.45 \\
\hline & & (7528) & (187) & (5) & (11) & (7289) & (174) & (5) & (9) \\
\hline \multirow[t]{2}{*}{ Portugal } & 29.59 & 23.90 & 18.83 & 18.46 & 17.18 & 16.62 & 14.27 & 18.75 & 14.44 \\
\hline & & (1021) & (248) & (2) & (20) & (1140) & (268) & (6) & (20) \\
\hline \multirow[t]{2}{*}{ Spain } & 34.06 & 26.02 & 24.64 & 26.17 & 19.47 & 24.93 & 21.57 & 24.04 & 19.12 \\
\hline & & (8636) & (589) & (154) & (44) & $(8685)$ & (594) & (148) & $(48)$ \\
\hline \multirow[t]{2}{*}{ Sweden } & 28.00 & 22.22 & 21.38 & 20.11 & 27.95 & 21.61 & 19.93 & 17.79 & 25.58 \\
\hline & & (24127) & (870) & $(43)$ & $(32)$ & (20457) & (618) & (43) & (20) \\
\hline \multirow[t]{2}{*}{ Switzerland } & 22.81 & 21.32 & 20.83 & 22.38 & 22.89 & 13.01 & 17.44 & 22.00 & 20.56 \\
\hline & & (451) & (903) & (5) & (79) & (490) & (920) & (4) & $(82)$ \\
\hline \multirow[t]{2}{*}{ United Kingdom } & 29.75 & 24.18 & 24.06 & 23.67 & 26.59 & 22.20 & 22.70 & 21.18 & 22.44 \\
\hline & & (33185) & (3697) & (77) & (243) & (33598) & $(3650)$ & $(80)$ & (245) \\
\hline \multirow[t]{2}{*}{ All countries } & & 25.46 & 25.09 & 24.44 & 24.44 & 23.90 & 23.60 & 22.61 & 22.95 \\
\hline & & (135578) & (13303) & (804) & (885) & (124666) & (12330) & (619) & (803) \\
\hline
\end{tabular}

Note: Statutory tax rates (STR) are calculated from OECD (2011). ETR1 is the first effective tax rate measure, calculated by dividing current tax expense by pre-tax income; and ETR2 is the second effective tax rate measure, calculated by dividing current tax expense by cash flow from operations. Sample period is between 2001 and 2008, inclusive. Number of observations for each ETR is reported in parenthesis. 
Table 4

Descriptive statistics

\begin{tabular}{lccccc}
\hline & Mean & $\begin{array}{c}\text { Standard } \\
\text { deviation }\end{array}$ & $25 \%$ & $50 \%$ & $75 \%$ \\
\hline Private firms $(N=135578)$ & & & & & \\
SIZE & 10.282 & 1.807 & 9.100 & 10.264 & 11.418 \\
LEV & 0.204 & 0.188 & 0.057 & 0.151 & 0.297 \\
PERF & 0.066 & 0.100 & 0.032 & 0.063 & 0.107 \\
CAPINT & 0.336 & 0.236 & 0.146 & 0.295 & 0.480 \\
INVINT & 0.182 & 0.159 & 0.042 & 0.152 & 0.279 \\
& & & & & \\
Public firms $(N=13303)$ & & & & & \\
SIZE & 12.152 & 1.748 & 10.928 & 12.134 & 13.481 \\
LEV & 0.162 & 0.145 & 0.045 & 0.128 & 0.239 \\
PERF & 0.052 & 0.132 & 0.034 & 0.068 & 0.107 \\
CAPINT & 0.270 & 0.215 & 0.098 & 0.223 & 0.386 \\
INVINT & 0.145 & 0.131 & 0.029 & 0.122 & 0.222
\end{tabular}

Private firms with tax haven operations $(N=804)$

$\begin{array}{lccccc}\text { SIZE } & 12.613 & 1.518 & 11.621 & 12.482 & 13.816 \\ \text { LEV } & 0.153 & 0.144 & 0.037 & 0.112 & 0.227 \\ \text { PERF } & 0.082 & 0.083 & 0.047 & 0.077 & 0.111 \\ \text { CAPINT } & 0.309 & 0.223 & 0.131 & 0.251 & 0.455 \\ \text { INVINT } & 0.132 & 0.132 & 0.017 & 0.099 & 0.196 \\ & & & & & \\ \text { Public firms with tax haven operations }(N=885) & & & & \\ \text { SIZE } & 13.671 & 1.401 & 12.811 & 13.998 & 14.771 \\ \text { LEV } & 0.183 & 0.143 & 0.067 & 0.167 & 0.262 \\ \text { PERF } & 0.079 & 0.080 & 0.044 & 0.074 & 0.111 \\ \text { CAPINT } & 0.288 & 0.221 & 0.116 & 0.224 & 0.395 \\ \text { INVINT } & 0.113 & 0.105 & 0.021 & 0.090 & 0.179\end{array}$

Note: SIZE is the natural log of total assets; $L E V$ is the ratio of total long-term debt to total assets; PERF is the ratio of pre-tax operating profit to total assets; CAPINT is the ratio of property, plant, and equipment to total assets; INVINT is the ratio of inventory to total assets. Sample period is between 2001 and 2008 , inclusive. 
Table 5

Correlation matrix

\begin{tabular}{|c|c|c|c|c|c|c|c|c|c|c|c|}
\hline \multicolumn{12}{|c|}{ Private firms $(N=135578)$} \\
\hline & TAXHAVEN & NONHAVENMNC & SIZE & $L E V$ & $P E R F$ & CAPINT & INVINT & $S T R$ & WWTS & HIGHTAXJUR & TAXCONF \\
\hline TAXHAVEN & 1 & & & & & & & & & & \\
\hline NONHAVENMNC & $-0.034 *$ & 1 & & & & & & & & & \\
\hline SIZE & $0.100 *$ & $0.249 *$ & 1 & & & & & & & & \\
\hline$L E V$ & $-0.021 *$ & $-0.110 *$ & 0.005 & 1 & & & & & & & \\
\hline PERF & $0.013 *$ & $0.024 *$ & $-0.018 *$ & $-0.084 *$ & 1 & & & & & & \\
\hline CAPINT & $-0.009 *$ & $-0.098 *$ & $0.044 *$ & $0.374 *$ & $-0.102 *$ & 1 & & & & & \\
\hline INVINT & $-0.025 *$ & $0.046 *$ & $-0.110 *$ & $-0.149 *$ & $0.056 *$ & $-0.410 *$ & 1 & & & & \\
\hline STR & $0.032 *$ & $0.075 *$ & $0.216 *$ & $-0.031 *$ & $0.022 *$ & $-0.054 *$ & $0.022 *$ & 1 & & & \\
\hline$W W T S$ & $-0.032 *$ & $-0.166 *$ & $0.035 *$ & $-0.047 *$ & $-0.138 *$ & $0.009 *$ & $-0.097 *$ & $-0.297 *$ & 1 & & \\
\hline HIGHTAXJUR & $0.029 *$ & $0.036 *$ & $0.321 *$ & $-0.116 *$ & $-0.068 *$ & $-0.069 *$ & $-0.030 *$ & $0.659 *$ & $0.260 *$ & 1 & \\
\hline TAXCONF & $-0.031 *$ & $0.056 *$ & $-0.115 *$ & $0.112 *$ & $0.101 *$ & $0.007 *$ & $0.062 *$ & $0.143 *$ & $-0.666 *$ & $-0.401 *$ & 1 \\
\hline
\end{tabular}

Public firms $(N=13303)$

\begin{tabular}{|c|c|c|c|c|c|c|c|c|c|}
\hline TAXHAVEN & 1 & & & & & & & & \\
\hline NONHAVENMNC & $-0.309 *$ & 1 & & & & & & & \\
\hline SIZE & $0.232 *$ & $0.201 *$ & 1 & & & & & & \\
\hline$L E V$ & $0.039 *$ & $-0.050 *$ & $0.201 *$ & 1 & & & & & \\
\hline PERF & $0.053 *$ & $0.110 *$ & $0.291 *$ & -0.010 & 1 & & & & \\
\hline CAPINT & $0.022 *$ & $-0.077 *$ & $0.162 *$ & $0.292 *$ & $0.058 *$ & 1 & & & \\
\hline INVINT & $-0.066 *$ & $0.089 *$ & $-0.050 *$ & $-0.104 *$ & $0.092 *$ & $-0.194 *$ & 1 & & \\
\hline STR & $-0.035 *$ & $0.088 *$ & $-0.037 *$ & -0.011 & $0.035 *$ & $-0.090 *$ & $0.053 *$ & 1 & \\
\hline WWTS & -0.002 & $-0.116 *$ & $-0.088 *$ & $0.019 *$ & $-0.084 *$ & $0.063 *$ & $-0.115 *$ & $-0.315 *$ & 1 \\
\hline HIGHTAXJUR & $-0.018 *$ & 0.010 & $-0.024 *$ & -0.016 & $0.021 *$ & $-0.038 *$ & -0.010 & $0.702 *$ & $0.174 *$ \\
\hline TAXCONF & $-0.035 *$ & $0.074 *$ & $0.023 *$ & $-0.019 *$ & $0.060 *$ & $-0.101 *$ & $0.072 *$ & $0.268 *$ & $-0.798 *$ \\
\hline
\end{tabular}

Note: TAXHAVEN is a dummy variable taking the value of 1 if a firm has a foreign subsidiary in a tax-haven jurisdiction and 0 otherwise; NONHAVENMNC is a dummy variable taking the value of 1 if a firm has a foreign subsidiary in a non-tax-haven jurisdiction and 0 otherwise; SIZE is the natural $\log$ of total assets; $L E V$ is the ratio of total long-term debt to total assets; $P E R F$ is the ratio of pre-tax operating profit to total assets; CAPINT is the ratio of property, plant, and equipment to total assets; INVINT is the ratio of inventory to total assets; STR is the statutory tax rate in each country and in each year; WWTS is a dummy variable taking the value of 1 if a firm is headquartered in a jurisdiction with a worldwide tax system and 0 otherwise; TAXCONF is a dummy variable taking the value of 1 if a firm is headquartered in a jurisdiction whose financial reporting is closely linked with tax reporting and 0 otherwise; HIGHTAXJUR is a dummy variable taking the value of 1 if a firm is headquartered in a jurisdiction whose corporate tax rate is higher than the median and 0 otherwise. Sample period is between 2001 and 2008 , inclusive.

* denotes significance at the $5 \%$ level or more. 
Table 6

The impact of tax havens on private vs. public firms' ETRs

\begin{tabular}{|c|c|c|c|c|c|c|}
\hline & \multicolumn{6}{|c|}{ Dependent Variable } \\
\hline & \multicolumn{3}{|c|}{ ETR1 } & \multicolumn{3}{|c|}{ ETR2 } \\
\hline & $\begin{array}{c}\text { Private } \\
(\mathrm{N}=135578)\end{array}$ & $\begin{array}{c}\text { Public } \\
(\mathrm{N}=13303)\end{array}$ & $\begin{array}{c}\text { Difference } \\
\text { Private-Public }\end{array}$ & $\begin{array}{c}\text { Private } \\
(\mathrm{N}=124666)\end{array}$ & $\begin{array}{c}\text { Public } \\
(\mathrm{N}=12330)\end{array}$ & $\begin{array}{c}\text { Difference } \\
\text { Private-Public }\end{array}$ \\
\hline TAXHAVEN & $\begin{array}{l}-0.0533 * * * \\
(0.0055)\end{array}$ & $\begin{array}{l}-0.0156 * * * \\
(0.0057)\end{array}$ & $\begin{array}{l}-0.0370 * * * \\
(0.0079)\end{array}$ & $\begin{array}{l}-0.0385 * * * \\
(0.0060)\end{array}$ & $\begin{array}{l}-0.0225 * * * \\
(0.0060)\end{array}$ & $\begin{array}{l}-0.0160 * \\
(0.0085)\end{array}$ \\
\hline \multicolumn{7}{|l|}{ Controls } \\
\hline NONHAVENMNC & $\begin{array}{l}-0.0039 * * * \\
(0.0013)\end{array}$ & $\begin{array}{r}0.0008 \\
(0.0032)\end{array}$ & $\begin{array}{r}-0.0047 \\
(0.0034)\end{array}$ & $\begin{array}{l}-0.0083 * * * \\
(0.0014)\end{array}$ & $\begin{array}{l}-0.0151 \text { *** } \\
(0.1167)\end{array}$ & $\begin{array}{l}0.0069 * \\
(0.0037)\end{array}$ \\
\hline SIZE & $\begin{array}{l}0.0077 \text { *** } \\
(0.0003)\end{array}$ & $\begin{array}{l}0.0064 \text { *** } \\
(0.0009)\end{array}$ & $\begin{array}{r}-0.0013 \\
(0.0010)\end{array}$ & $\begin{array}{l}0.0063 * * * \\
(0.0003)\end{array}$ & $\begin{array}{l}0.0052 \text { *** } \\
(0.0010)\end{array}$ & $\begin{array}{r}0.0011 \\
(0.0010)\end{array}$ \\
\hline$L E V$ & $\begin{array}{l}-0.1359 * * * \\
(0.0026)\end{array}$ & $\begin{array}{l}-0.1261 * * * \\
(0.0100)\end{array}$ & $\begin{array}{r}-0.0098 \\
(0.0103)\end{array}$ & $\begin{array}{l}-0.0096 * * * \\
(0.0029)\end{array}$ & $\begin{array}{l}-0.0481 * * * \\
(0.0111)\end{array}$ & $\begin{array}{l}0.0385 \text { *** } \\
(0.0115)\end{array}$ \\
\hline PERF & $\begin{array}{l}0.1647 \text { *** } \\
(0.0039)\end{array}$ & $\begin{array}{l}0.2723 \text { **** } \\
(0.0086)\end{array}$ & $\begin{array}{l}-0.1076 * * * \\
(0.0094)\end{array}$ & $\begin{array}{l}0.3676 \text { **** } \\
(0.0052)\end{array}$ & $\begin{array}{l}0.3429 \text { *** } \\
(0.0119)\end{array}$ & $\begin{array}{l}0.0247 * \\
(0.0130)\end{array}$ \\
\hline CAPINT & $\begin{array}{l}-0.1081 * * * \\
(0.0023)\end{array}$ & $\begin{array}{l}-0.0687 \text { *** } \\
(0.0068)\end{array}$ & $\begin{array}{l}-0.0393 * * * \\
(0.0071)\end{array}$ & $\begin{array}{l}-0.1865 * * * \\
(0.0024)\end{array}$ & $\begin{array}{l}-0.1579 * * * \\
(0.0074)\end{array}$ & $\begin{array}{l}-0.0286 * * * * \\
(0.0077)\end{array}$ \\
\hline INVINT & $\begin{array}{l}-0.0969 * * * \\
(0.0031)\end{array}$ & $\begin{array}{l}-0.0443 \text { **** } \\
(0.0111)\end{array}$ & $\begin{array}{l}-0.0526 * * * \\
(0.0115)\end{array}$ & $\begin{array}{l}-0.0198 * * * \\
(0.0035)\end{array}$ & $\begin{array}{l}-0.0583 * * * \\
(0.0129)\end{array}$ & $\begin{array}{l}0.0385 \text { *** } \\
(0.0134)\end{array}$ \\
\hline STR & $\begin{array}{l}0.6209 * * * \\
(0.0287)\end{array}$ & $\begin{array}{l}0.3090 \text { *** } \\
(0.0896)\end{array}$ & $\begin{array}{l}0.3116 \text { **** } \\
(0.0940)\end{array}$ & $\begin{array}{l}0.5128 \text { **** } \\
(0.0362)\end{array}$ & $\begin{array}{l}0.2548 \text { *** } \\
(0.0034)\end{array}$ & $\begin{array}{l}0.2580 * * \\
(0.1220)\end{array}$ \\
\hline Constant & $\begin{array}{l}0.0152 \\
0.0123\end{array}$ & $\begin{array}{l}0.1574 * * * \\
0.0424\end{array}$ & $\begin{array}{l}-0.1422 \text { *** } \\
0.0441\end{array}$ & $\begin{array}{c}-0.0252 * \\
0.0145\end{array}$ & $\begin{array}{l}0.1384 * * * \\
0.0491\end{array}$ & $\begin{array}{l}-0.1636 \text { *** } \\
0.0511\end{array}$ \\
\hline Country effects included & Yes & Yes & & Yes & Yes & \\
\hline Sector effects included & Yes & Yes & & Yes & Yes & \\
\hline Year effects included & Yes & Yes & & Yes & Yes & \\
\hline$N$ & 135578 & 13303 & & 124666 & 12330 & \\
\hline$F$-stat & $663.21 * * *$ & $72.13 * * *$ & & $751.72 * * *$ & $75.26 * * *$ & \\
\hline$R^{2}$ & 0.1535 & 0.1292 & & 0.15807 & 0.1705 & \\
\hline
\end{tabular}

Note: ETR1 is the first effective tax rate measure calculated by dividing current tax expense by pre-tax income; ETR2 is the second effective tax rate measure calculated by dividing current tax expense by cash flow from operations. TAXHAVEN is a dummy variable taking the value of 1 if a firm has a foreign subsidiary in a tax-haven jurisdiction and 0 otherwise; NONHAVENMNC is a dummy variable taking the value of 1 if a firm has a foreign subsidiary in a non-tax-haven jurisdiction and 0 otherwise; SIZE is the natural $\log$ of total assets; $L E V$ is the ratio of total long-term debt to total assets; PERF is the ratio of pre-tax operating profit to total assets; CAPINT is the ratio of property, plant, and equipment to total assets; INVINT is the ratio of inventory to total assets; $S T R$ is the statutory tax rate in each country and in each year. Sample period is between 2001 and 2008, inclusive. For each variable, robust standard errors are reported in parenthesis. $* * *, * *, *$ denote significance at the $1 \%, 5 \%$, and $10 \%$ levels, respectively. 
Table 7

Tax haven operations and ETRs of private vs. public firms

\begin{tabular}{|c|c|c|c|c|}
\hline & \multicolumn{2}{|c|}{ Model 1} & \multicolumn{2}{|c|}{ Model 2} \\
\hline & ETRl & ETR2 & ETR1 & ETR2 \\
\hline \multirow[t]{2}{*}{ PRIVATE } & $0.0232 * * *$ & $0.0044 * * *$ & $0.0207 * * *$ & 0.0027 \\
\hline & $(0.0017)$ & $(0.0018)$ & $(0.0017)$ & $(0.0018)$ \\
\hline \multirow[t]{2}{*}{ TAXHAVEN } & $-0.0177 * * *$ & $-0.0212 * * *$ & $-0.0177 * * *$ & $-0.0145 * * *$ \\
\hline & $(0.0051)$ & $(0.0054)$ & $(0.0051)$ & $(0.0055)$ \\
\hline \multirow[t]{2}{*}{ PRIVATE*TAXHAVEN } & $-0.0341 * * *$ & $-0.0157 * *$ & $-0.0341 * * *$ & $-0.0336 * * *$ \\
\hline & $(0.0074)$ & $(0.0080)$ & $(0.0074)$ & $(0.0059)$ \\
\hline Controls & yes & yes & yes & yes \\
\hline Country/Sector/Year effects & yes & yes & yes & yes \\
\hline$N$ & 148881 & 136996 & 148881 & 136996 \\
\hline$F$-stat & $674.9109 * * *$ & $689.82 * * *$ & $619.6735 * * *$ & $783.82 * * *$ \\
\hline$R^{2}$ & 0.149 & 0.148 & 0.135 & 0.1913 \\
\hline \multicolumn{5}{|c|}{$\begin{array}{l}\text { Note: ETRI is the first effective tax rate measure calculated by dividing current tax expense by pre-tax income; ETR } 2 \text { is the } \\
\text { second effective tax rate measure calculated by dividing current tax expense by cash flow from operations. PRIVATE is a } \\
\text { dummy variable taking the value of } 1 \text { if a firm is privately-held and } 0 \text { if a firm is publicly-listed; TAXHAVEN is a dummy } \\
\text { variable taking the value of } 1 \text { if a firm has a foreign subsidiary in a tax-haven jurisdiction and } 0 \text { otherwise. We estimate } \\
\text { Models } 1 \text { and } 2 \text { using the ordinary least square and weighted least square regressions, respectively. We include the same } \\
\text { control variables as in Table } 6 \text {. Country, sector and year fixed effects are also included in each specification. Sample period } \\
\text { is between } 2001 \text { and } 2008 \text {, inclusive. For each variable, robust standard errors are reported in parenthesis. ***, **, * denote } \\
\text { significance at the } 1 \%, 5 \% \text { and } 10 \% \text { levels, respectively. }\end{array}$} \\
\hline
\end{tabular}


Table 8

Home-country characteristics and ETRs of private vs. public firms

\begin{tabular}{|c|c|c|}
\hline & \multicolumn{2}{|c|}{ Dependent variables } \\
\hline & ETR1 & ETR2 \\
\hline \multicolumn{3}{|c|}{ Panel A: Home country tax system } \\
\hline \multicolumn{3}{|l|}{$W W T S$} \\
\hline PRIVATE & $\begin{array}{l}0.0405 * * * \\
(0.0030)\end{array}$ & $\begin{array}{l}0.0221 \text { *** } \\
(0.0031)\end{array}$ \\
\hline TAXHAVEN & $\begin{array}{r}-0.0092 \\
(0.0109)\end{array}$ & $\begin{array}{l}-0.0405 * * * \\
(0.0099)\end{array}$ \\
\hline PRIVATE*TAXHAVEN & $\begin{array}{l}-0.0689 * * * \\
(0.0199)\end{array}$ & $\begin{array}{l}-0.0397 * * \\
(0.0183)\end{array}$ \\
\hline \multicolumn{3}{|l|}{$T T S$} \\
\hline PRIVATE & $\begin{array}{l}0.0462 \text { *** } \\
(0.0019)\end{array}$ & $\begin{array}{l}0.0289 \text { *** } \\
(0.0021)\end{array}$ \\
\hline TAXHAVEN & $\begin{array}{l}-0.0228 * * * \\
(0.0058)\end{array}$ & $\begin{array}{l}-0.0138 * * * \\
(0.0064)\end{array}$ \\
\hline PRIVATE*TAXHAVEN & $\begin{array}{l}-0.0327 * * * \\
(0.0081)\end{array}$ & $\begin{array}{l}-0.0201 * * * \\
(0.0091)\end{array}$ \\
\hline Controls & yes & yes \\
\hline Country/Sector/Year effects & yes & yes \\
\hline$N$ & 148881 & 136996 \\
\hline$\chi^{2}$ & 1522.37 & 1877.05 \\
\hline Prob $>\chi^{2}$ & 0.001 & 0.001 \\
\hline \multicolumn{3}{|l|}{ Panel B:Book-tax conformity } \\
\hline \multicolumn{3}{|l|}{ High TAXCONF } \\
\hline PRIVATE & $\begin{array}{l}0.0619 \text { *** } \\
(0.0021)\end{array}$ & $\begin{array}{l}0.0378 \text { *** } \\
(0.0023)\end{array}$ \\
\hline TAXHAVEN & $\begin{array}{r}-0.0107 \\
(0.0066)\end{array}$ & $\begin{array}{r}-0.0041 \\
(0.0073)\end{array}$ \\
\hline PRIVATE*TAXHAVEN & $\begin{array}{l}-0.0504 * * * \\
(0.0115)\end{array}$ & $\begin{array}{r}-0.0197 \\
(0.0130)\end{array}$ \\
\hline \multicolumn{3}{|l|}{ Low TAXCONF } \\
\hline PRIVATE & $\begin{array}{l}0.0245 \text { *** } \\
(0.0024)\end{array}$ & $\begin{array}{l}0.0177 \text { *** } \\
(0.0026)\end{array}$ \\
\hline TAXHAVEN & $\begin{array}{l}-0.0304 * * * \\
(0.0078)\end{array}$ & $\begin{array}{l}-0.0079 * * * \\
(0.0050)\end{array}$ \\
\hline PRIVATE*TAXHAVEN & $\begin{array}{l}-0.0227 * * \\
(0.0101)\end{array}$ & $\begin{array}{r}-0.005 \\
(0.0104)\end{array}$ \\
\hline Controls & yes & yes \\
\hline Country/Sector/Year effects & yes & yes \\
\hline$N$ & 148881 & 136996 \\
\hline$\chi^{2}$ & 1282.66 & 1877.05 \\
\hline Prob $>\chi^{2}$ & 0.001 & 0.001 \\
\hline
\end{tabular}

Note: ETRl is the first effective tax rate measure calculated by dividing current tax expense by pre-tax income; ETR2 is the second effective tax rate measure calculated by dividing current tax expense by cash flow from operations. WWTS is a dummy variable taking the value of 1 if a firm is headquartered in a jurisdiction with a worldwide tax system and 0 otherwise; TTS is a dummy variable taking the value of 1 if a firm is headquartered in a jurisdiction with a territorial tax system and 0 otherwise; TAXCONF is a dummy variable taking the value of 1 if a firm is headquartered in a jurisdiction whose financial reporting is closely linked with tax reporting and 0 otherwise. PRIVATE is a dummy variable taking the value of 1 if a firm is privately- held and 0 otherwise; TAXHAVEN is a dummy variable taking the value of 1 if a firm has a foreign subsidiary in a tax-haven jurisdiction and 0 otherwise. We include the same control variables as in Table 6. Country, sector and year fixed effects are also included in each specification. Sample period is between 2001 and 2008, inclusive. For each variable, robust standard errors are reported in parenthesis. $* * *, * *, *$ denote significance at the $1 \%, 5 \%$ and $10 \%$ levels, respectively. 